\title{
PHENOLIC CARBOXYLIC ACIDS FROM Sempervivum
}

ruthenicum

L. A. Gumenyuk

UDC 547.972

On studying the flowers and leaves of Sempervivum ruthenicum we isolated from them a series of flavonol compounds [1-3], and from the leaves, together with flavonoid derivatives, we also obtained phenolic carboxylic acids with $\mathrm{R}_{f} 0.30$ and $0.37\left(2 \% \mathrm{CH}_{3} \mathrm{COOH}\right)$.

These compounds were fractionated with ethyl acetate from the acidified aqueous solution with subsequent separation on polyamide solvent. The phenolic acids were extracted from the organic phase with half-saturated aqueous sodium carbonate solution, and the extracts were acidified with sulfuric acid to $\mathrm{pH}$ 3 and treated with ethyl acetate. The ethyl acetate extract, after the solvent had been driven off, was separated on a column of Kapron with elution first by water and then by $50 \%$ ethanol, as a result of which two substances were isolated.

Substance I, $\mathrm{C}_{9} \mathrm{H}_{8} \mathrm{O}_{4}, \mathrm{mp} 194-197^{\circ} \mathrm{C}$ (mp of the acetyl derivative 196-198 ${ }^{\circ} \mathrm{C}$ ). UV spectrum: $\lambda_{\max }$ 328 and $234 \mathrm{~nm}$, characteristic for phenolic compounds [4].

Substance $\Pi, \mathrm{C}_{25} \mathrm{H}_{24} \mathrm{O}_{12}, \mathrm{mp} 228-231^{\circ} \mathrm{C}$ (mp of the acetylation product $103-105^{\circ} \mathrm{C}$ ).

From their physicochemical properties, derivatives, and chromatographic studies with authentic samples, substance (I) was identified as 3,4-dihydroxycinnamic (caffeic) acid, and substance (II) as 1,4dicaffeylquinic acid.

\section{TERAT URE CITED}

1. P. A. Gnedkov and L. A. Gumenyuk, in: Chemical Investigations in Pharmacy [in Russian], Kiev (1970), p. 149.

2. L. A. Gumenyuk, P. A. Gnedkov, and V. S. Batyuk, Khim. Prirodn. Soedin., $\underline{6}, 630$ (1970).

3. L. A. Gumenyuk, P. A. Gnedkov, and V. S. Batyuk, Khim. Prirodn. Soedin., $\overline{\underline{z}}, 369$ (1.971).

4. I. P. Kovalev and V. I. Litvinenko, Khim. Prirodn. Soedin., 1, 233 (1965).

Zaporozhe Medical Institute. Translated from Khimiya Pri rodnykh Soedinenii, No. 4, p. 525, JulyAgusut, 1971. Original article submitted March 25, 1.971.

- 1973 Consultants Bureau, a division of Plenum Publishing Corporation, 227 West 17th Street, New York, N.Y. 10011. All rights reserved. This article cannot be reproduced for any purpose whatsoever without permission of the publisher. A copy of this article is available from the publisher for $\$ 15.00$. 